\title{
СОЦИАЛЬНО-ЭКОНОМИЧЕСКИЕ ПРОЦЕССЫ В СТАРОПРОМЫШЛЕННЫХ МОНОГОРОДАХ. ФАКТОРЫ УСТОЙЧИВОГО РАЗВИТИЯ
}

\author{
А.Д. РИЗОВ \\ аспирант кафедры «Общая экономическая теория» Санкт-Петербургского государственного \\ экономического университета, факультет региональной экономики и управления
}

\section{Аннотация}

К социально-экономическим процессам в стадии трансформации отнесены процессы на рынке труда, миграция коренного населения, демографические процессы. Характер динамики социально-экономических процессов старопромышленных моногородов указывает на неблагоприятное влияние на них экономических процессов в условиях трансформации последних под влиянием факторов микро-, мезо-, макро- и мега-уровня, внутренней и внешней среды самих старопромышленных моногородов. В статье определены подходы к решению научнопрактической проблемы обеспечения устойчивого развития старопромышленных моногородов, выявлены факторы, наиболее влияющие на состояние старопромышленных моногородов, включая трансформации их социально-экономических процессов.

\section{Abstract}

Processes in the labor market, migration, demographic processes are social and economic processes, they are in a stage of transformation. Economic processes are transformed under the influence of factors of micro-, meso-, macro-and mega-level internal and external environment monotowns. Dynamics of socio-economic processes in the old industrial monocities indicates that the transformation of economic processes adversely affect them.

Цель данной работы - определить подходы к решению научно-практической проблемы обеспечения устойчивого развития старопромышленных моногородов, решив при этом задачу определения факторов, наиболее влияющих на изменение траектории развития старопромышленных моногородов в современных условиях, включая трансформации их социально-экономических процессов.

К социально-экономическим процессам в стадии трансформации мы отнесли процессы на рынке труда (безработица, занятость, кадровое обеспечение), миграцию коренного населения, демографические процессы. Характер их динамики указывает на неблагоприятное влияние экономических процессов моногорода в условиях трансформации последних под влиянием факторов микро-, мезо-, макро- и мега-уровня внутренней и внешней среды моногорода. Этим обусловлена необходимость разработки мер по изменению неблагоприятных тенденций развития социально-экономических процессов моногородов, их стабилизации, а в дальнейшем, их выводу на траекторию, соответствующую благоприятным тенденциям развития. Реализация данных мер 
проводится через конкретные мероприятия, которые целесообразно условно объединить в особые блоки, первый из которых связан с диверсификацией экономики моногородов и реструктуризацией их градообразующих предприятий. Второй - c развитием гражданского общества, активно участвующего в планировании и контроле социально-экономического развития территории проживания. Наконец, третий - с развитием благоприятной среды проживания, который будет рассмотрен более подробно в настоящей статье.

В условиях диверсификации экономики старопромышленных моногородов в современных условиях динамичной рыночной среды депрессивные моногорода находятся в зоне особой группы риска. Их социально-экономические процессы характеризуются негативными тенденциями, включая процессы на рынке труда, миграцию коренного населения, демографические процессы. Для российских старопромышленных моногородов не характерны тенденции гуманизации среды проживания, экологического приоритета развития, формирования индивидуального облика города, сохранения исторической застройки. Исторический облик этих городов теряет индивидуальность ввиду типовой застройки, расширения производственных площадок, выноса зон отдыха за пределы центра города, ограниченности «зеленых зон».

Проблемы развития старопромышленных моногородов исследовались целым рядом российских экономистов. Так, концептуальные подходы к разработке стратегии их развития изложены в трудах Н.И. Перминовой, А.И. Татаркина, вопросы управления рассмотрены в работах Н.И. Крысина, международные стандарты в области социальной ответственности представлены в трудах Н.В. Гуняевой, теоретические аспекты социально-экономических процессов нашли отражение в статьях Л.П. Бураковой. Среди зарубежных авторов, исследовавших социальноэкономические процессы в моногородах, проблемы в сфере занятости (безработицы), миграции, повышения доходов населения, реструктуризации градообразующих предприятий и диверсификации экономики моногородов, следует назвать Alperlts, Willink, Sarasvathy, Bazen, Bijleveld, Koopman и др., а из исследовавших проблемы развития регионов и расселения - Й. Тюнена, А. Вебера, В. Лаунхардта.

Складывающаяся модель расселения на территории старопромышленных моногородов повышает расходы жителей на транспорт, приводит увеличению затрат на развитие инженерной и транспортной инфраструктуры, ухудшению экологической обстановки, удлиняет путь маятниковой миграции. Актуальным становится поиск способов повышения привлекательности и комфортности старопромышленных моногородов, например, через проекты регенерации территорий (их оживление, обновление для вовлечения в экономическую жизнь моногорода) путем сочетания инженерно-транспортных объектов, административно-деловых учреждений и предприятий культурно-бытового обслуживания населения, а также жилой застройки разной этажности и комфортности. Сами проекты включают, наряду с пространственными и архитектурными решениями, социально-экономические, правовые, организационные, финансовые и другие мероприятия. 
Особенно значимой становится задача привлечения частных инвестиций к разработке и реализации проектов развития территорий и городской среды старопромышленных моногородов на основе государственно-частного партнерства, взаимовыгодных для бизнеса, государства и города условиях. Следует также учесть успешный зарубежный опыт регенерации и реновации территорий. Примером японского опыта по возрождению индустриальных моногородов служат Кобэ, Тикухо Кита-Кюсю, Онода, Сакаи, Нагоя, Хиросима, Убэ и др. Возрождение старопромышленного моногорода проследим на примере района Тикухо, расположенного на острове Кюсю. Его угольная промышленность играла ведущую роль в развитии Японии в период с конца XIX в. до 50-х годов XX в. Начиная с 1950 г., в связи с переходом на новые энергоносители, целый ряд угольных шахт в Японии подлежал закрытию. В 1976 г. в Тикухо прекратила существование последняя шахта. (Попутно заметим, что закрытая в тот период угольная шахта Мицуи в районе Тикухо в настоящее время функционирует как музей). Это привело к резкому обострению социально-экономических проблем: безработице, сокращению населения, миграции.

Решением проблемы возрождения региональной экономики Тикухо стал проект создания автомобильного промышленного кластера. Лишь спустя 16 лет, в качестве стратегического инвестора удалось привлечь Тойота Мотор к строительству сборочного завода в Мията (городской округ «Мията»), а также другие предприятия в автомобильный кластер. Это привело к увеличению населения городского округа Мията, его объединению с соседними муниципалитетами и обретению им в 2006 г. высокого административного статуса - город Миявака.

Таким образом, старые угольные поля уступили место индустриальным паркам, что стало результатом привлечения стратегических инвесторов других регионов Японии. Были решены следующие задачи: снижение безработицы, увеличение налоговых поступлений, продуктивного использования территорий региона и расположенных там промышленных объектов при помощи как местных инвесторов, так и инвесторов извне региона. Привлечение последних наиболее важны: сторонние инвесторы не только улучшают производство и менеджмент, но и повышают технологический уровень предприятий и бизнеса.

Особое внимание было сконцентрировано на подготовке кадров для автомобильного кластера. Актуальной была координация со стороны местного и национального правительства. Традиционной мерой реструктуризации и возрождения моногородов для Японии является обязательное назначение ответственных за проект, в данном случае поиск и привлечение стратегических инвесторов. Основная часть финансирования была осуществлена из бюджета префектуры, и лишь небольшая часть - правительством страны. В итоге местными предприятиями были получены крупные заказы запущенного и функционирующего к тому времени автомобильного кластера. Практика района Тикухо привела к выводу: территорию угольных полей можно использовать под индустриальные зоны (парки). Опыт организации угольной промышленности был использован как потенциал развития инфраструктуры, включая 
транспортную (железные дороги, морские порты, автодороги, аэропорты), для формирования и развития индустриальных парков.

Анализ опыта японских депрессивных регионов, испытывавших аналогичные российским моногородам проблемы, приводит к следующим обобщениям. На первом этапе проводится оценка ресурсов старопромышленного моногорода по направлениям (промышленность, торговля, жилье, образование), наличие и качество транспортно-логистической инфраструктуры; по промышленным предприятиям (динамика занятых в отраслях, зависимость экономики моногорода от градообразующего предприятия); анализ других отраслей промышленности, возможностей моногорода по развитию промышленности, востребованной в регионе более широкого уровня.

Проведение второго этапа связано с анализом примеров восстановления экономики зарубежных староромышленных моногородов, изучением путей процесса восстановления в Японии, США, Великобритании, Ирландии, Италии и т.д.

Третий этап - анализ участия государственных органов власти в проектах возрождения старопромышленных моногородов. Стратегия предусматривает разработку концепции возрождения монопрофильной территории; учет политики по устойчивому развитию градообразующих предприятий, связанных с ними отраслей и бизнес-структур; программу занятости населения, трудовой миграции, обучения и переобучения кадров, исследование влияния инвестиций в градообразующие предприятия моногорода на занятость и развитие промышленности, с учетом связанных отраслей промышленности; изучение и выполнение взятых перед моногородом обязательств со стороны органов государственной власти.

Главным выводом японского опыта является важность создания реальной и эффективной инвестиционной среды, разработки и реализации конкретных проектов в рамках государственночастного партнерства. При этом практически все данные проекты направлены на формирование благоприятной среды проживания, что во многом решает проблемы миграции населения трудоспособного возраста, включая молодежь.

Проблемы российских старопромышленных моногородов во многом схожи с проблемами зарубежных депрессивных городов и регионов. Старопромышленные моногорода на территории страны формировались, в основном, вокруг индустрии, вокруг городского предприятия. Прежние драйверы их развития в кризис 2008-2009 гг. перестали работать, возникла проблема нового смысла, вокруг которого сфокусировалась бы цель жизни старопромышленного моногорода. Как другой фактор развития качественно новой среды моногорода - формирование среднего класса, достигающего от 15\% до 25\% населения России. Его представители сосредоточены, прежде всего, в крупных и средних городах, предъявляя особый спрос на качество жизни: качественное образование, качественное здравоохранение, качественное жилье, безопасность, качественный транспорт, доступность, качественный досуг и т.д., что не характерно для российских старопромышленных моногородов.

Конкурентные преимущества старопромышленных моногородов могут быть связаны с климатическими условиями, территориальным

расположением, культурой, 
достопримечательностями, их историей, национальным колоритом, ремесленными традициями, местной кухней, гостеприимством, знаменитостями, яркими личностями прошлого или настоящего времени и т.д. Особое место в новом импульсе развития моногорода может занять имидж старопромышленного моногорода, разработка его бренда, подчеркивающего его неповторимость и уникальность его истории, населения, экономики, природы, архитектуры, достижений. Создание удачного бренда, формирование, поддержание или мероприятия по ребрендингу моногорода могут стать основой привлечения потока инвестиций. Начинается работа с определения целей: привлечение инвестиций, развитие туризма, интерес жителей, стимулирование предложения товаров и услуг предприятий, фирм моногорода и др.

При анализе предпосылок модернизации старопрмышленных моногородов выявлены: низкий профессиональный уровень управления предприятиями; низкая производственная культура; технологическое отставание российских предприятий от лидеров мирового рынка; низкий уровень кооперации между предприятиями отрасли и международной кооперации; неразвитая инфраструктура городов; высокие административные барьеры; отсутствие или значительное отставание от требований времени технической и экономической нормативной документации; низкая активность и мобильность населения особо выделен негативный имидж моногородов [1].

Брендинг моногородов обладает особенностями, поскольку именно их схожесть требует нового подхода к проблеме. Сами монопрофильные городские и сельские поселения, оказавшись перед угрозой диверсификации экономики, в условиях реструктуризации градообразющего предприятия, его модернизации, связанного с этим сокращением участия предприятия в социальном развитии монопоселений, вынуждены рассматривать другие направления экономического развития территории. В первую очередь, это сервисные направления, например, туризм, включая сельский, событийный (спортивный, этнографический, литературный, гастрономический, религиозный, цветочный, исторический, выставочный, связанный с событиями в мире моды и др.). Позиционирование монопоселений требует выявление особых, индивидуальных черт, позволяющих подчеркнуть их особенную привлекательность. Поиск индивидуальности как принцип лежит в основе выбора стратегического направления развития.

Наиболее общим направлением является предложение целого спектра услуг, связанных с рекламой, администрированием, управлением, консалтингом. Туризм в старопромышленных моногородах, на первый взгляд, экономически невыгоден, однако, зарубежный опыт предлагает много примеров размещения художественных выставок, концертных площадок, промышленных музеев, картинных галерей, творческих мастерских именно на бывших промышленных территориях, шахтах [2]. Самобытность, особенности культуры монопоселений могут рассматриваться и как возможность развития направления по организации культурнопредставительских мероприятий, концертов.

Возможности самостоятельного развития молодежной культуры могут быть предложены через решение пространственного планирования территории моногорода, предусматривающего 
наличие зоны развлекательного отдыха с кафе, спортивными площадками, клубами. Такого же внимания требует и размещение жилья в моногороде - в экологически чистой зоне, комплексно благоустроенной, с развитой инфраструктурой, в первую очередь - транспортной. Все эти преимущества или потенциальные, реализуемые, перспективные направления развития моногорода, вплетенные в канву бренда, послужат главной его цели - привлечению инвестиций для устойчивого развития старопромышленного моногорода.

Приведем примеры успешного брендинга российских моногородов. Великий Устюг (Вологодская область, Северо-Западный ФО). Пятнадцать лет назад было придумано, что город является резиденцией Деда Мороза, и он качественно изменился. Плес (Ивановская область, Центральный ФО) - маленький разрушенный городок, в настоящее время испытывает большой недостаток гостиничного фонда из-за наплыва туристов. Абрау-Дюрсо (Краснодарский край, Южный ФО) - город, развивающий винный туризм - пользующееся высоким спросом модное направление туристического бизнеса во всем мире.

Для формирования благоприятной и креативной среды в моногородах, сохранения и обеспечения доступности культурного наследия, самобытности культуры и традиций российских моногородов актуальным становится определение путей использования информационнокоммуникационных инноваций [3]. Особую роль играет сохранение и развитие базовых ценностей российского общества, встраиваемых в вектор развития социально-экономических процессов старопромышленных моногородов. Инновации в различных сферах влияют на формирование личности, зачастую находят отражение в трансформации нравственных и культурных основ. Их сочетания с устойчивыми ценностями активно влияют на формирование человеческого капитала, тем более, что многочисленные исследования экономического роста связаны с указанным внеэкономическим аспектом.

Значительная часть населения России, включая жителей моногородов, является не только наблюдателем, но и активным участником информационной революции. Сотовые телефоны и модемный доступ в интернет сменились разветвленной сетью беспроводного мобильного интернета, что привело к развитию и постоянной связи потребителей с сетью через социальные сети. Данный факт свидетельствует о возможности использования информационнокоммуникационной среды для решения задач становления, формирования и развития человеческого капитала в условиях старопромышленных моногородов. В качестве социальных проектов, связанных с широкими возможностями информационных технологий для развития человеческого капитала, можно привести такие проекты как телемедицина, дистанционное обучение, электронное правительство, социальные услуги. Для развития и поддержки культурнонравственных ценностей в моногородах российских регионах активно продвигаются такие проекты, как домашний оперный театр, домашняя филармония, виртуальный домашний музей.

Значительное территориальное пространство РФ и многочисленные миграционные потоки в направлении мегаполисов диктуют необходимость для старопромышленных моногородов использование современных интернет-технологий для обеспечения оказания качественных и 
доступных услуг в сфере культуры и искусства. Компьютеризация и обеспечение доступа в интернет продвигается благодаря национальным и региональным программам развития территорий и не связано непосредственно с обеспечением населения услугами в сфере культуры и искусства. Информационные технологии и их применение в различных областях жизнедеятельности способствуют формированию благоприятной среды проживания, обеспечивают принципиально новое ее качество, привлекают в комфортную и гостеприимную среду, благодаря их клиентоориентированности.

В заключение сделаем вывод, что наряду с социально-экономическими факторами эффективного социально-экономического развития старопромышленных моногородов необходимо включение, учет и исследование «мягких факторов», таких как среда проживания, наличие инфраструктуры знаний, культуры, здравоохранения, связи, спорта, близость рынка.

\section{ЛИТЕРАТУРА}

1. Ильина И.Н. Стратегия модернизации моногородов России/Развитие монопрофильных населенных пунктов в Российской Федерации: сборник научных трудов. М.: Финансовый университет, 2012, с. 8.

2. Бетехтина А.В. Брендинг монопрофильных и «закрытых» городов. Материалы Всероссийской научно-практической конференции «Брендинг малых и средних городов России: опыт, проблемы, перспективы. Екатеринбург, Изд-во Уральского университета, 2012. Электронный pecypc http://igup.urfu.ru/docs/SbornGeobrend2012.pdf (дата обращения 12.02.2014).

3. Угольникова О.Д. Социально-экономические проблемы моногородов. Монография./ О.Д. Угольникова, Ж. Базен, П. Бейлевельд, Р. Коупман, А.Д. Ризов, В.В. Угольников / - СПб.: СПбГУСЭ, 2012, с. 80-117. 